\title{
Direct and fast detection of Alexandrium minutum algae by using high frequency microbalance
}

\author{
Célia Sousa $^{a, b, c}$, Chantal Compère ${ }^{d}$, Catherine Dreanno ${ }^{d}$, Marie-Pierre Crassous ${ }^{d}$, Fabienne Gas ${ }^{e}$, \\ Beatrice Baus ${ }^{\mathrm{e}}$, Hubert Perrot ${ }^{\mathrm{a}, \mathrm{b}, \text { * }}$
}

\author{
a Sorbonne Universités, UPMC Univ Paris 06, UMR 8235, Laboratoire Interfaces et Systèmes Electrochimiques, \\ F-75005 Paris, France \\ ${ }^{\mathrm{b}}$ CNRS, UMR 8235, LISE, F-75005 Paris, France

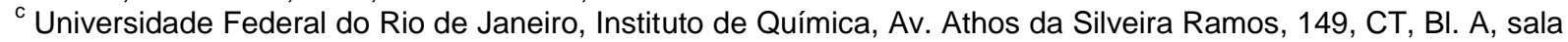 \\ 408, Ilha da Cidade Universitária, CEP: 21.941-909 Rio de Janeiro, RJ, Brazil \\ ' IFREMER, Centre de Brest, Laboratoire Détection, Capteurs et Mesures, F-29280 Plouzané, France \\ e CEA Marcoule, Direction des Sciences du Vivant, iBEB/SBTN/LDCAE, F-30200 Bagnols sur Cèze, France

\begin{abstract}
:
In this paper, a simple detection of a toxic algae, Alexandrium minutum, was developed using highly sensitive quartz crystal microbalance. In terms of performance, compared with other conventional analytical tools, the main interest of our immunosensor is based on a fast and direct detection of these living cells. This system requires the use of one monoclonal antibody directed against the surface antigen of $A$. minutum. We demonstrate that the whole living and motile algae are caught and detected. The high specificity of the biosensor is also demonstrated by testing several other dinoflagellate species. The frequency shift is correlated to the A. minutum cell concentration. This simple system is potentially promising for environmental monitoring purposes.
\end{abstract}

Keywords : Alexandrium minutum ; Quartz microbalance ; Microalgae ; Immunosensor 


\section{Introduction}

Although the red tides, called harmful algal blooms (HABs), are a natural occurring phenomenon, in the last decades, they have become a serious environmental and economic problem due to their adverse impact on the ecosystem and on human health (Hallegraeff, 1993, Van Dolah, 2000). Their frequency, intensity and geographic ranges have seriously increased since the 1970's. The increasing occurrence of algal blooms reflects the alteration in ecological systems as a consequence of human activities. HABS are often attributed to eutrophication, ballast water introduction and climate change (Hallegraeff, 2010). They are, nowadays, considered as one of the major problems that coastal countries must face, and it seems that this will be even greater in the near future (Masó and Garcés, 2006). In Europe, the genus Alexandrium is often involved in paralytic shellfish poisoning (PSP) events. The current method for the accurate identification of this dinoflagellate is based on the microscopic examination of its specific morphological features. This procedure requires considerable broad taxonomic expertise, it is time consuming and costly. As a result, the rapid high throughput of samples is beyond the detection capabilities of most monitoring programs and does not effectively prevent or mitigate the adverse effects of these toxic events. Consequently, improved, reliable and cost effective monitoring methods are urgently needed. The application of biosensor technology is ideal for marine environmental monitoring and detection as the sensors are portable and provide selective and rapid responses in real time in the field (Kröger et al., 2005; Zielinski et al., 2009).

Various types of sensors are currently being developed to detect microorganisms in biological and environmental samples. They are based on different transducers such as optical, electrochemical, gravimetric systems and several sensitive layers like immunomolecules or nucleic acid molecules. Quartz crystal microbalance (QCM) technology is particularly interesting for environmental monitoring and diagnosis due to its rapid analysis, satisfactory sensitivity, simple low cost instrumentation (Hao et al., 2009) and has become widely used for pathogen detection (Olsen et al., 2003, Buchatip et al., 2010; Hong et al., 2009; Shen et al., 2011, Guntupalli et al., 2012 ). The immunosensors are advantageous since they can be based on the direct detection of the whole cell through antibody selective layers immobilized on the transducer surface. The key feature of this approach is to obtain suitable antibodies particularly in terms of affinity and specificity. Nakanishi et al. (1996) were pioneers in using a conventional QCM and different methods of antibody immobilization to detect Chatonella marina. Electrical sensing combined with carbon nanotube structures was recently set up to detect Aureococcus anophagefferens (Ishikawa et 
al., 2009). Nucleic sensors are currently developed since their specificity appears to be excellent (Nayak et al., 2009). However, these systems do not allow the direct detection of whole targeted microorganisms. Preliminary steps of preparation such as cell lysis and targeted DNA amplification are needed before performing the detection step. Nevertheless, sophisticated sensors have already been designed thanks to conventional DNA immobilizations, through electrochemical detection (Diercks et al., 2008), optical detection (Lagier et al., 2007) or gravimetric detection (Gamby et al., 2008; Lazerges et al., 2006). An electrochemical genosensor for the detection of Alexandrium minutum was developed by Diercks et al., (2008). This system uses oligonucleotide probes hybridizing rRNA genes in the ribosomes of target cells. It depends on the rRNA content of the cells, but the rRNA level varies according to the cell growth cycle leading to error estimations in cell concentrations.

A sophisticated Environmental Sample Processor (ESP) based on nucleic hybridization was successfully designed for detecting plankton and microorganisms in the field in real time (Scholin et al. 2001, 2010). This autonomous device is state of the art technology and nowadays it is too costly for routine environmental monitoring in any national program. In France, recurrent blooms of Alexandrium minutum mainly occurred in Brittany (f.i Bay of Morlaix, Penzé estuary, Bay of Brest, Rance estuary). These yearly blooms developed in the period June-July and often reached cell concentrations $>1 \times 10^{5}$ cells $\mathrm{L}^{-1}$. For sanitary monitoring purposes, when the alert threshold of $10000 \mathrm{cell} \mathrm{L}^{-1}$ is exceeded, biotoxin analysis is then performed in shellfishes. Therefore, the sensitivity of the biosensor or monitoring system needed to meet this alert threshold. It could be achieved by the immunosensor itself or by combining a phytoplankton concentration step prior the detection analysis.

In this paper, we explore for the first time, the possibility of using QCM as a simple, rapid and label free method to detect and quantify directly Alexandrium minutum algae after a simple and single step of concentration. The monoclonal antibody is prepared against this microalgae and is immobilized on the gold electrodes of quartz resonators. Fast and in situ measurements are obtained using high frequency microbalance based on a stable and thermoregulated oscillator. The limits of detection, the dose responses and the selectivity of this QCM sensor are carefully evaluated.

\section{Materials and Methods}

2.1 Quartz Microbalance apparatus 
$9 \mathrm{MHz}$ AT-cut planar quartz crystals (14 mm diameter) were purchased from RAKON company (RAKON FRANCE, Mougins, France). Two identical gold electrodes were deposited on both sides of the crystal with a standard keyhole shape and they were connected to a BNC connector. The crystal was mounted between two O-Ring seals inserted in a Plexiglas cell whose chamber volume was about $50 \mu \mathrm{L}$. Only one side of the quartz resonator was in contact with the solution. To produce a flow system, a P-1 peristaltic pump (Pharmacia) was connected to the chamber; a constant flux $\left(70 \mu \mathrm{L} \mathrm{min}{ }^{-1}\right)$ of solutions was maintained during the experiments. A homemade oscillator was designed to drive the quartz crystal at $27 \mathrm{MHz}$ ( $3^{\text {rd }}$ overtone). A frequency counter (Philips PM 6685) was coupled to the QCM to monitor the microbalance frequency, $\mathrm{f}_{\mathrm{m}}$. (Fig. 1A). Under the gravimetric regime, a linear relationship was obtained between the mass change, $\Delta \mathrm{m}$, due to the different interactions on the resonator surface and the frequency change, $\Delta \mathrm{f}_{\mathrm{m}}$. At a $27 \mathrm{MHz}$ resonant frequency, a theoretical value of $0.36 \mathrm{ng} \mathrm{Hz}^{-1}$ was deduced and an experimental value of 0.35 ng Hz${ }^{-1}$ was used according to Bizet et al., (2000) and to Rodriguez-Pardo et al., (2004).

To validate the gravimetric regime of such a device, electroacoustic measurements were performed on this system under the same experimental conditions. The experimental set up was based on a standard network analyzer (HP 4194A) and was computer-controlled through a lab made software written in $\mathrm{HP}_{-V E E}{ }^{\circledR}$ language. Electrical admittance measurements were automatically carried out with a $10 \mathrm{mV}$ perturbation signal at 201 frequencies around the resonance frequency. They were monitored in real time during the different reactions and the equivalent circuit could be estimated (Garcia-Jareno et al., 2000). The series resonant frequencies, $f_{s}$, and the motional resistance, $R$, were extracted during the experiments every 1.5 minutes.

\subsection{Chemical reagents}

Phosphate buffered saline solution (PBS; $137 \mathrm{mM} \mathrm{NaCl}, 2.7 \mathrm{mM}, \mathrm{KCl}, 10 \mathrm{mM}$ $\mathrm{Na}_{2} \mathrm{HPO}_{4} .2 \mathrm{H}_{2} \mathrm{O}, 2 \mathrm{mMKH}_{2} \mathrm{PO}_{4}, \mathrm{pH}$ 7.4,), $\mathrm{H}_{2} \mathrm{SO}_{4} 95 \%, \mathrm{H}_{2} \mathrm{O}_{2} 30 \%, \mathrm{HCl}, \mathrm{NaCl}$, Bovine Serum Albumin (BSA) were purchased from Sigma Aldrich. All the other chemicals used in this study were analytical grade.

\subsection{Immobilization of the monoclonal antibody against Alexandrium minutum cells}

The AMI6 monoclonal antibody against A. minutum was selected because of its high specificity for this study. The production, specificity and characteristics have been previously 
reported (Gas et al., 2009, 2010). This IgG was purified on a protein G HiTrap1® affinity column (GE Healthcare Life Sciences) prior to immobilization and diluted in PBS at the final concentration of $100 \mu \mathrm{g} \mathrm{mL}^{-1}$.

The gold-coated QCM electrodes were cleaned by soaking in a Piranha solution (30\% $\mathrm{H}_{2} \mathrm{O}_{2}$ and concentrated $\mathrm{H}_{2} \mathrm{SO}_{4}, 1: 3 \mathrm{v} / \mathrm{v}$ ) for $20 \mathrm{~min}$, rinsed thoroughly with distilled water and then, dried under argon prior to assembling them in the QCM cell. The cleaned electrodes were flushed with $0.1 \mathrm{M} \mathrm{HCl}$, distilled water and then PBS. The antibody solution flowed through the QCM cell for 90 minutes at ambient temperature. The excess and unbound antibodies were removed by rinsing the chamber with PBS for 30 minutes. Then, a PBS solution containing $1 \%$ BSA solution was injected for 10 minutes to block any non-specific interactions that might occur between the gold substrate and antigens (Brewer et al., 2005). After the antibody immobilization step, PBS, free of BSA flowed through the QCM cell until the stabilization of the base line (Fig1B).

\subsection{Dinoflagellate strains and cultures}

All the microalgae strains, Alexandrium minutum, Heterocapsa triquetra, Karenia mikimotoi and Alexandrium catenella came from IFREMER's collection. They are indicated by using letters A (A. minutum), H (H. triquetra), K (K. mikimotoi), AC (A. catenella), respectively. The phytoplankton strains were cultivated using natural seawater enriched $f / 2$ medium (Guillard, 1975). This methodology is commonly used for phytoplankton culture (Andersen, 2005) and is justified in a recent study about the use of quantitative LFIA test using the same monoclonal antibody (paper in preparation). Tests were performed with several stages of a phytoplankton culture and several A. minutum strains coming from different genetic populations and geographic areas. We did not observe any significant difference or bias to quantify the A. minutum cells in these various samples using the calibration curves set up with A. minutum coming from our laboratory cultures.

The cultures were grown at $18 \pm 1^{\circ} \mathrm{C}$ under cool-white fluorescence light, at a photon flux of $150 \mu \mathrm{E} / \mathrm{m}^{2} / \mathrm{s}$ with 14:10 LD photoperiod. At the end of the exponential growth phase, the cells were harvested by centrifugation $(5000 \mathrm{~g}, 10 \mathrm{~min})$ and kept frozen at $-20^{\circ} \mathrm{C}$ for later. Frozen and living cells were both used in the experiments. The microalgae medium culture used in the QCM experiment was also called working solution (WS).

The algae cultures were also concentrated by using a convenient and quick procedure. The cell suspensions were filtered on cellulose filter papers with particle retention levels down to $2.5 \mu \mathrm{m}$ (Whatman) and then, the recovered algae were resuspended with the WS. In 
order to determine the cell concentration before each QCM experiment, one milliliter of algal suspension was sampled and fixed with a drop of lugol's iodine solution and the cells were counted under a light microscope using a haemacytometer (Karlson et al., 2010).

\subsection{Quartz crystal microbalance measurements}

The same experimental procedure was followed for all the QCM measurements. The working solution, WS, was injected through the detection cell until stabilization before the injection of the same solution containing the selected algae at a given concentration. After one hour of circulation with the algae solution, the WS and the WS diluted at $50 \%$ with distilled water flowed through the QCM cell for 20 minutes and 10 minutes respectively. It should be noted that the immunosensors obtained were single used and for each detection experiment a new quartz resonator was prepared.

At the end of each experiment, the quartz crystal resonator was carefully removed from the cell, dipped in distilled water, dried, maintained in a glass container and a formaldehyde drop was deposited on the gold surface before scanning electron microscopy (SEM) observations. This fixation step allowed good preservation of the immobilized algae. Additionally, a direct estimation of the algal coverage rate was estimated for each picture through a Brucker soft (Area Fraction Report).

\subsection{Scanning electronic microscopy analysis}

The scanning electron analysis was carried out according to the protocol of Gas et al. (2009). The quartz crystal resonators were observed using a Quanta 200 instrument (FEI Company, Hillsboro, Oregon, USA).

\section{Results and discussion}

\subsection{Non specific interactions}

Firstly, the response of the microbalance sensor without the presence of antibodies on the gold surface was examined by using living cells and frozen cells in the WS (data not shown). The gold electrode surface was previously covered by a thin BSA layer directly adsorbed. In each case, the relative microbalance frequency change, $\Delta \mathrm{f}_{\mathrm{m}}$, was negligible $(5 \mathrm{~Hz}$ $<\Delta \mathrm{f}_{\mathrm{m}}$ ) demonstrating that there was no interaction between the BSA coated surface and the microalgae solution even when highly concentrated cell suspensions were injected ([A. minutum $]>1.10^{7}$ cells $/ \mathrm{L}$ ). Thus, the BSA was used to saturate free sites on the gold electrode 
and then, unspecific interaction was reduced to a minimum ratio in this way. These results were also confirmed by SEM, no cell was observed on the QCM sensor (data not shown).

\subsection{Direct detection of Alexandrium minutum algae}

Figure 2 shows the direct detection of Alexandrium minutum cells with the QCM when the AMI6 antibody was adsorbed on its surface. When the monoclonal antibody solution flowed through the microcell, a microbalance frequency change of $-500 \mathrm{~Hz}$ was observed. This steep decrease in frequency is due to the immobilization of these antibodies by direct adsorption onto the surface. The other change in frequency between the blocking step by BSA and the washing step by WS is related to the different compositions of these solutions. It is well known that the QCM device is sensitive to a change in viscosity/density and conductivity of the solution (Arnau, 2008).

When the living algae were injected through the chamber after the saturation step, a fast and steep microbalance frequency change, $\Delta \mathrm{f}_{\mathrm{m}}$, of $-540 \mathrm{~Hz}$ was observed reflecting the interactions between the modified gold surface and the living cells suspended in the WS. After $30 \mathrm{~min}$, the microbalance frequency reached a plateau. When WS was injected during this last phase, the microbalance frequency remained constant demonstrating that the interactions between the antibodies against the algae were very strong i.e cells stayed on the surface since no mass change was detected. The experiments have been repeated and reasonable standard deviations were found for this technique in the range of a few tenths of percent.

After the detection of Alexandrium minutum cells by the functionalized QCM sensor, the surface of the gold electrode was observed by SEM. In figures 3a and 3b, images of the algae cells were captured by the QCM sensor. In figure 3a, a large surface was explored, indicating the number of cells present on the whole surface. The coverage rate could be deduced through SEM analysis by taking the mean number of algae observed on the surface. A value of $10-15 \%$ was directly determined here through the Brucker software estimation. The Alexandrium minutum shape can be considered as a hemispheric shell and a diameter of 10-15 $\mu \mathrm{m}$ can be roughly estimated (figure 3B). According to the morphological observations reported on the same microalgae species by several authors (Probert, 1999; Labry et al., 2008), the same order of magnitude in parameters was also obtained. Then, an estimated mass per cell can be calculated by taking into account a cell density of $1200 \mathrm{~kg} \mathrm{~m}^{-3}$ and a volume of $810^{-15} \mathrm{~m}^{-3}$ if an hemispheric shell is used with a $15 \mu \mathrm{m}$ diameter. It should be noted that this 
volume is in agreement with the observations of Lim (Lim et al., 2005). Therefore, a weight value of $9.610^{-12} \mathrm{~kg}$ per cell is obtained. In figure 2 , the microbalance changes, $\Delta \mathrm{f}_{\mathrm{m}}$, is estimated at $-540 \mathrm{~Hz}$ which leads, in terms of mass change, to $194 \mathrm{ng}$ by considering the gravimetric regime validated. Then, the theoretical number of algae is around 20, which corresponds to a surface coverage rate of $0.05 \%$. However, a value of $10-15 \%$ was obtained by SEM analysis. This difference can be explained by electroacoustic measurements. In figure $4 \mathrm{~A}$, the relative series resonant frequency, $\Delta \mathrm{f}_{\mathrm{s}}$, is plotted against time during the detection step. Regarding figure 2, using the standard microbalance approach, the microbalance frequency changes, $\Delta \mathrm{f}_{\mathrm{m}}$, present a similar shift compared with $\Delta \mathrm{f}_{\mathrm{s}}$ and the time constant is in the same order of magnitude. The two systems of detection, conventional microbalances or electroacoustic admittances, give the same response. The validity of the gravimetric regime can be controlled through the calculation of the ratio, $\frac{\Delta R}{\Delta f_{s}}$, which appears as a pertinent variable for this purpose (Lucklum et al., 1999, 2000). A transient with large values was observed several minutes during the cell interaction before reaching a stationary value around $+8 \Omega \mathrm{Hz}^{-1}$ shown in figure $4 \mathrm{~B}$. In this present case, it means that the gravimetric regime of the microbalance is questionable. This idea is already underlined in other examples where cells are detected by QCM (Pomorska et al., 2010). When this type of biomolecules is detected, the gravimetric regime is not well respected. In this way, the number of captured cells estimated through QCM measurements can be inaccurate. This may explain the difference in surface coverage estimated through the QCM approach and the SEM analysis. Moreover, it strengthens the necessity to build a calibration curve for any biomolecules to be quantified in order to obtain the correct concentration.

\subsection{Calibration curves for Alexandrium minutum detection}

A calibration curve is obtained by measuring the microbalance frequency shift, $\Delta \mathrm{f}_{\mathrm{m}}$, at the same time of interaction at different algae concentrations (Figure 5). A good linear fitting was obtained in our concentration range with a correlation coefficient, $R$, of -0.99 . A direct estimation of an unknown concentration of Alexandrium minutum cells in environmental samples can be then deduced. The detection limit seems to be around $1.10^{6}$ cells. $\mathrm{mL}^{-1}$ under our experimental conditions. These detection ranges are in agreement with previous studies using QCM immunosensor detecting other microorganisms (Hong et al., 2009) and a marine microalgae species, Chattonella marina (Nakanishi et al., 1996). 


\subsection{Detection of Karenia mikimotoi, Alexandrium catenella, Heterocapsa triquetra}

The specificity of a biosensor is essential for developing a safe detection tool for environmental monitoring. The specificity was tested with the main toxic species monitored on our coasts. In order to study the specificity of our system, the affinity of the functionalized QCM immunosensor was evaluated by using different dinoflagellates, showing the same shape or frequently found in the same ecological niche. Samples of Karenia mikimotoi, Alexandrium catenella, Alexandrium minutum and Heterocapsa triquetra were injected into the QCM immunosensor (Figure 6a and 6b). As a result, a significant $\Delta \mathrm{f}_{\mathrm{m}}$ was only observed in the presence of $A$. minutum. For the other algae species, a steady microbalance frequency signal was observed indicating that nonspecific interactions did not occur. The AMI6 antibody demonstrates a very high specificity for A. minutum since it does not cross-react with K. mikimotoi, A. catenella and H. triquetra cells. Each graph represents one experiment done on the same modified resonator in a continuous way after successive additions of the different algae. In our case, a single use is proposed as this tool can be used as a first indicator.

\section{Conclusion}

The feasibility of a direct and fast detection of a toxic algae Alexandrium minutum is demonstrated in this work by using a $27 \mathrm{MHz}$ microbalance incorporated into a microcell. In terms of gravimetric interpretation, our acoustic device can not accurately estimate the mass of algae immobilized after the detection steps. This result is due to the shape, size, mechanical properties and the way of interaction of these specific biomolecules. The gravimetric regime is only retained when uniform and purely elastic films are deposited on the QCM surface. This result strengthens the need to set up correlation curves for any new microorganisms. In terms of selective identification, stability, cost and simple use, this biosensor shows very attractive potentialities for environmental monitoring. However, even if this system is suitable for some bloom samples, the relative lack of sensibility of this biosensor could easily be overcome by a preliminary concentration of the sea water sample.

\section{Acknowledgments}

This work is part of the HAB-SEACHIP project, supported by a grant from the ANR PRECODD program. 


\section{Figure captions}

Figure 1:

Schematic illustration of the experimental QCM detection system (a) and functionalized QCM sensor by monoclonal AMI6 antibodies (b)

Figure 2:

Direct and fast detection of living cells $\left(5.6 .10^{6}\right.$ cells. $\left.\mathrm{mL}^{-1}\right)$ through QCM measurements after modification of the gold electrode with adsorbed antibodies against Alexandrium minutum.

Figure 3:

Scanning electron pictures of the gold electrode after the capture of Alexandrium minutum (living cells) by antibodies adsorbed on gold interaction at different scales (a, scale bar : 500 um, b, scale bar : 5 um).

Figure 4: Electroacoustic measurements during algae detection: a) Changes in the resonant frequency series, $\Delta \mathrm{f}_{\mathrm{s}}$, and b) Changes in the variable, $\frac{\Delta \mathrm{R}}{\Delta \mathrm{f}_{\mathrm{s}}}$, of the quartz resonator during the algae detection, living cells $\left(5.6 \times 10^{6}\right.$ cells $\left.\mathrm{mL}^{-1}\right)$.

Figure 5:

Calibration curve obtained with different cell concentrations of Alexandrium minutum

Figure 6: Specificity of the QCM immunosensor

a) Detection of Karenia mikimotoi $\left(2.8 .10^{6}\right.$ cells. $\left.\mathrm{mL}^{-1}\right)$, Alexandrium catenella $\left(6.8 .10^{5} \mathrm{~mL}^{-1}\right)$ and Alexandrium minutum $\left(1.5 .10^{6}\right.$ cells. $\left.\mathrm{mL}^{-1}\right)$ and b) detection of Heterocapsa triquetra $\left(2.5 .10^{6}\right.$ cells. $\left.\mathrm{mL}^{-1}\right)$ with antibodies adsorbed on the gold electrode of the microbalance. 


\section{References}

Andersen, RA., 2005. Algal culturing techniques, Elsevier, p 565.

Arnau, A., 2008. Piezoelectric Transducers and applications, Ed A. Arnau, $2^{\text {nd }}$ Edition, Springer, Berlin. p 525.

Bizet, K., Gabrielli, C., Perrot, H., 2000. Immunodetection by quartz crystal microbalance - A new approach for direct detection of rabbit IgG and peroxidase. Appl. Biochem. Biotech. 89, 139-149.

Brewer, S.H., Glomm, W.R., Johnson, M.C., Knag, M.K., Franzen, S., 2005. Probing BSA binding to citrate-coated gold nanoparticles and surfaces. Langmuir 21, 9303-9307.

Buchatip, S., Ananthanawat, C., Sithigorngul, P., Sangvanich, P., Rengpipat, S., Hoven, V.P., 2010. Detection of the shrimp pathogenic bacteria, Vibrio harveyi, by a quartz crystal microbalance-specific antibody based sensor. Sens. Actuator B-Chem. 145, 259-264.

Diercks, S., Metfies, K., Medlin, L.K., 2008. Development and adaptation of a multiprobe biosensor for the use in a semi-automated device for the detection of toxic algae. Biosens. Bioelectron. 23, 1527-1533.

Gamby, J., Lazerges, M., Girault, H.H., Deslouis, C., Gabrielli, C., Perrot, H., Tribollet, B., 2008. Electroacoustic polymer microchip as an alternative to quartz crystal microbalance for biosensor development. Anal. Chem. 80, 8900-8907.

Garcia-Jareno, J.J., Gabrielli, C., Perrot, H., 2000. Validation of the mass response of a quartz crystal microbalance coated with Prussian Blue film for an electrogravimetry. Electrochem. Commun. 2, 195-200.

Gas, F., Pinto, L., Baus, B., Gaufres, L., Crassous, M.P., Compere C., Quemeneur E., 2009. Monoclonal antibody against the surface of Alexandrium minutum used in a whole-cell ELISA. Harmful Algae 8, 538-545.

Gas, F., Baus, B., Pinto, L., Compere, C., Tanchou, V., Quemeneur, E., 2010. One step immunochromatographic assay for the rapid detection of Alexandrium minutum. Biosens. Bioelectron. 25, 1235-1239.

Guillard, R.R.L., 1975. Culture of phytoplankton for feeding marine invertebrates. In: Smith, W.L., Chanley, M.H. (Eds.), Culture of Marine Invertebrate Animals. Plenum Press, New York, USA, pp. 26-60.

Guntupalli, R., Sorokulova, I., Olsen, E., Globa, L., Pustovyy, O., Moore, T., Chin, B., Barbaree, J., Vodyanoy, V., 2012. Detection and identification of methicillin resistant and sensitive strains of Staphylococcus aureus using tandem measurements. J. Microbiol. Methods 90, 182-191 
Hallegraeff, G.M., 1993. A review of harmful algal blooms and their apparent global increase. Phycologia 32, 79-99.

Hallegraeff, G.M., 2010. Ocean climate change, phytoplankton community responses, and harmful algal blooms: a formidable predictive challenge. J. Phycol. 46, 220-235.

Hao, R., Wang, D., Zhang, X., Zuo, G., Wei, H., Yang, R., Zhang, Z., Cheng, Z., Guo, Y., Cui, Z., Zhou, Y., 2009. Rapid detection of Bacillus anthracis using monoclonal antibody functionalized QCM sensor. Biosens. Bioelectron. 24, 1330-1335.

Hong, S.R., Choi, S.J., Do-Jeong, H., Hong, S., 2009. Development of QCM biosensor to detect a marine derived pathogenic bacteria Edwardsiella tarda using a novel immobilisation method. Biosens. Bioelectron.24, 1635-1640.

Ishikawa, F.N., Stauffer, B., Caron, D.A., Zhou, C., 2009. Rapid and label-free cell detection by metal-cluster-decorated carbon nanotube. Biosens. Bioelectron. 24, 2967-2972.

Karlson, B., Cusack, C, Bresnan, E., 2010. Microscopic and molecular methods for quantitative phytoplankton analysis. Intergovernmental Oceanographic Commission of UNESCO, Paris, 109 pp.

Kröger, S., Law R.J., 2005. Biosensors for marine applications we all need the sea, but does the sea need biosensors ? Biosens. Bioelectron. 20, 1903-1913.

Labry, C., Erard-Le Denn, E., Chapelle, A., Fauchot, J., Youenou, A., Crassous, M.P., Le Grand, J., Lorgeoux, B., 2008. Competition for phosphorus between two dinoflagellates: A toxic Alexandrium minutum and a non-toxic Heterocapsa triquetra. J. Exp. Mar. Biol. Ecol. $358,124-135$.

Lagier, M.J., Jack, W.F.B., Goodwin, K.D., 2007. Electrochemical detection of harmful algae and other microbial contaminants in coastal waters using hand-held biosensors. Mar. Pollut. Bull. 54, 757-770.

Lazerges, M., Perrot, H., Zeghib, N., Antoine, E., Compere, C., 2006. Oligonucleotide quartz crystal microbalance sensor for the microalgae Alexandrium minutum (Dinophyceae). Sens. Actuator B-Chem. 120, 329-337.

Lim, P.T., Ogata, T., 2005. Salinity effect on growth and toxin production of four tropical Alexandrium species (Dinophyceae). Toxicon, 45, 699-710.

Lucklum, R., Behling, C., Hauptmann, P., 1999. Role of mass accumulation and viscoelastic film properties for the response of acoustic-wave based chemical sensors. Anal. Chem. 71, 2488-2496.

Lucklum, R., Behling, C., Hauptmann, P., 2000. Gravimetric and non-gravimetric chemical quartz resonators, Sens. Actuator B-Chem. 65, 277-283.

Masó, M., Garcès, E., 2006. Harmful microalgae blooms (HAB) next term; problematic and conditions that induce them. Mar. Pollut. Bull. 53, 620-630. 
Nakanishi, K., Karube, I., Hiroshi, S., Uchida, A., Ishida, Y., 1996. Detection of the red tidecausing plankton Chattonella marina using a piezoelectric immunosensor. Anal. Chim. Acta $325,73-80$.

Nayak, M., Kotian, A., Marathe, S., Chakravortty, D., 2009. Detection of microorganisms using biosensors -A smarter way towards detection techniques. Biosens. Bioelectron. 25, 661667.

Pomorska, A., Shchukin, D., Hammond, R., Cooper, M.A., Grundmeier, G., Johannsmann, D., 2010. Positive frequency shifts observed upon adsorbing micron-sized solid objects to a quartz crystal microbalance from the liquid phase. Anal. Chem. 82, 2237-2242.

Olsen, E.V., Pathirana, ST., Samoylov, A.M., Barbaree, J.M., Chin, B.A., Neely, W.C., Vodyanoy, V., 2003. Specific and selective biosensor for Salmonella and its detection in the environment. J. Microbiol. Methods 53, 273-285.

Probert, I., 1999. Sexual reproduction and ecophysiology of the marine dinoflagellate Alexandrium minutum Halim. PhD thesis, University of Westminster, Ifremer Brest, London, $99 \mathrm{pp}$.

Rodriguez-Pardo, L., Farina, J., Gabrielli, C., Perrot, H., Brendel, R., 2004. Resolution in quartz crystal oscillator circuits for high sensitivity microbalance sensors in damping media. Sens. Actuator B-Chem. 103, 318-324.

Scholin, C.A., Massion, E.I., Wright, D.K., Cline, D.E., Mellinger, E., Brown, M., 2001. Aquatic autosampler device. U.S. Pat. No. 6187530

Scholin, C.A., 2010. What are "ecogenomic sensors?" A review and thoughts for the future. Ocean science 6, 51-60.

Shen, Z.Q., Wang, J.F., Qiu, Z.G., Jin, M., Wang, X.W., Chen, Z.L., Li, J.W., Cao, F.H., 2011. QCM immunosensor detection of Escherichia coli O157:H7 based on beacon immunomagnetic nanoparticles and catalytic growth on colloidal gold. Biosens. Bioelectron. 26, 3376-3381.

Van Dolah F.M., 2000. Marine algal toxins: origins, health effects, and their increased occurrence. Environ Health Perspect. 108:133-141

Zielinski, O., Busch, J.A., Cembella, A.D., Daly, K.L., Engelbrektsson, J., Hannides, A.K., Schmidt, H., 2009. Detecting marine hazardous substances and organisms: sensors for pollutants, toxins and pathogens. Oceans Science 5, 329-349. 

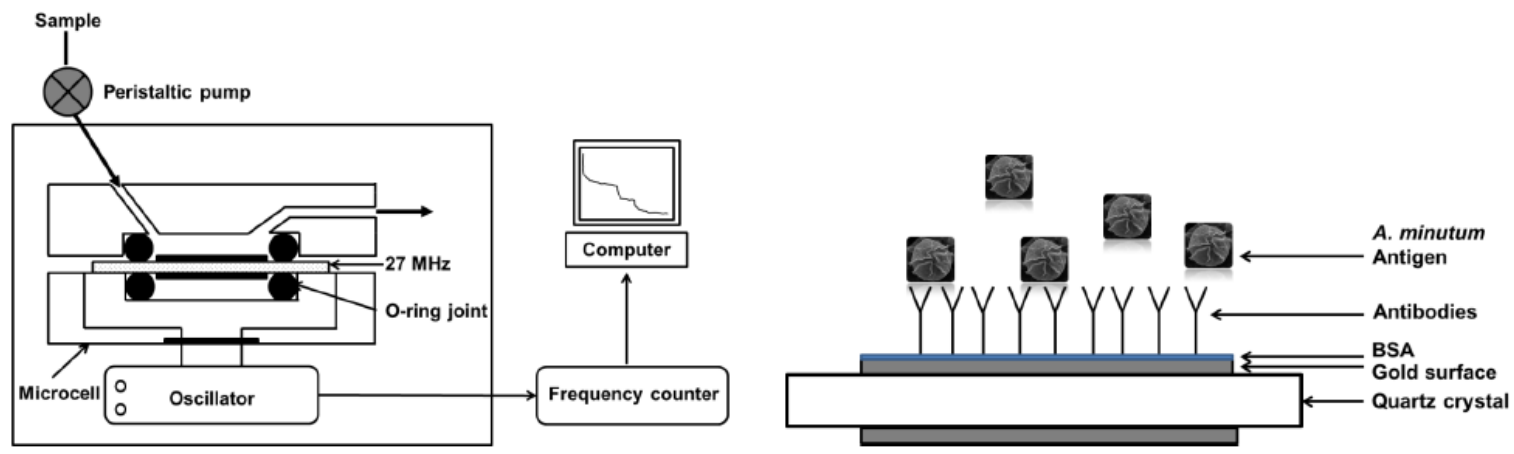
Figure2

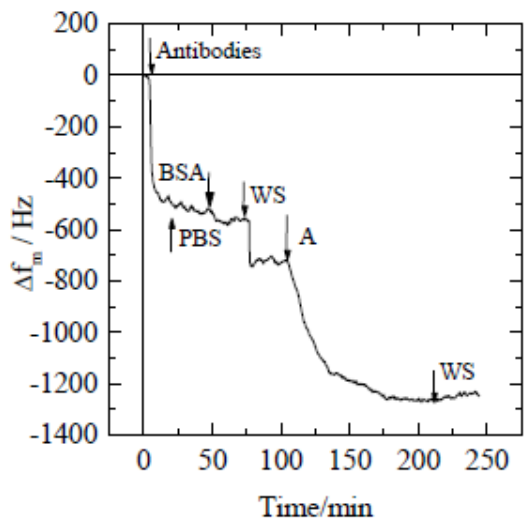


Figure3
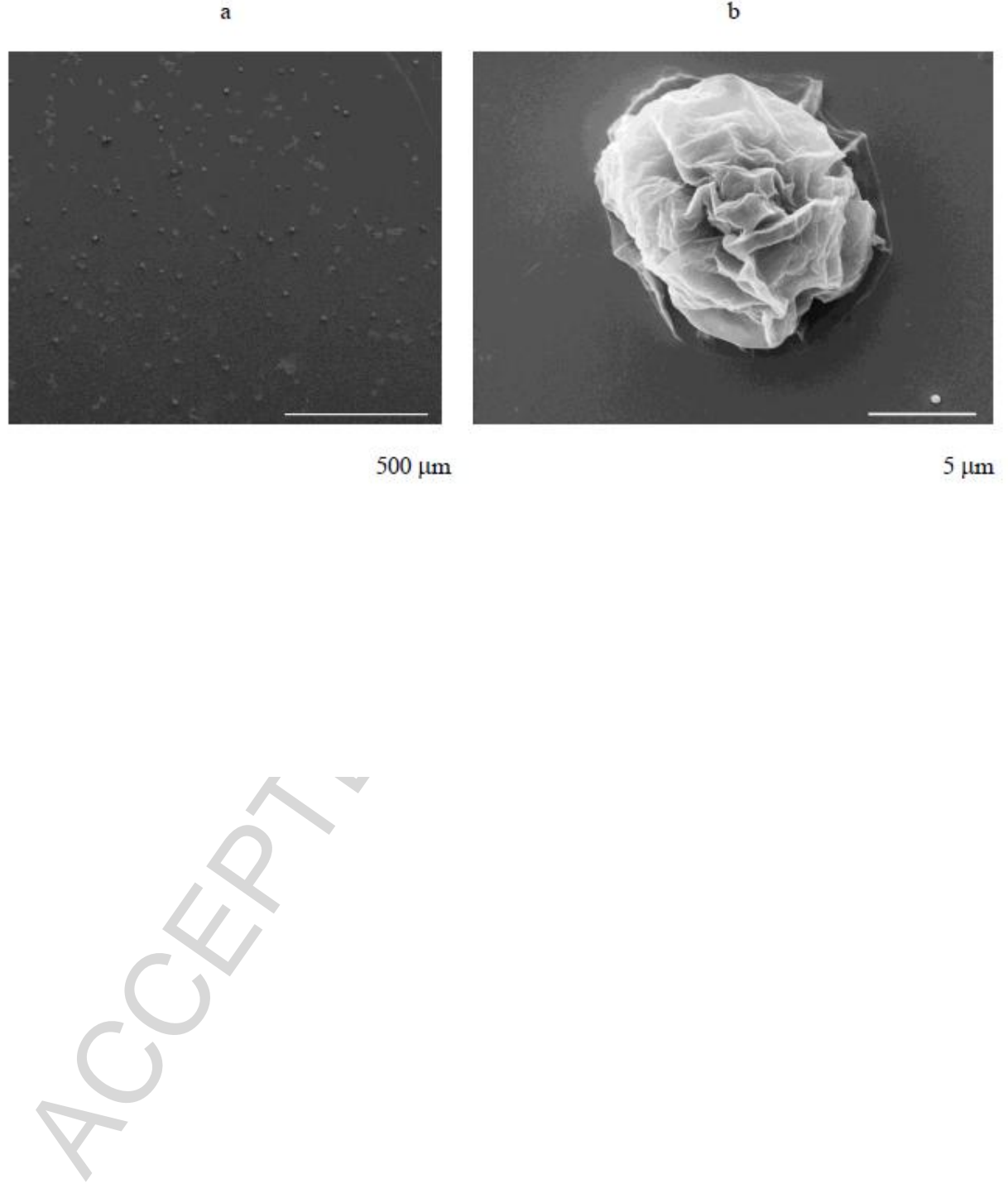
Figure4
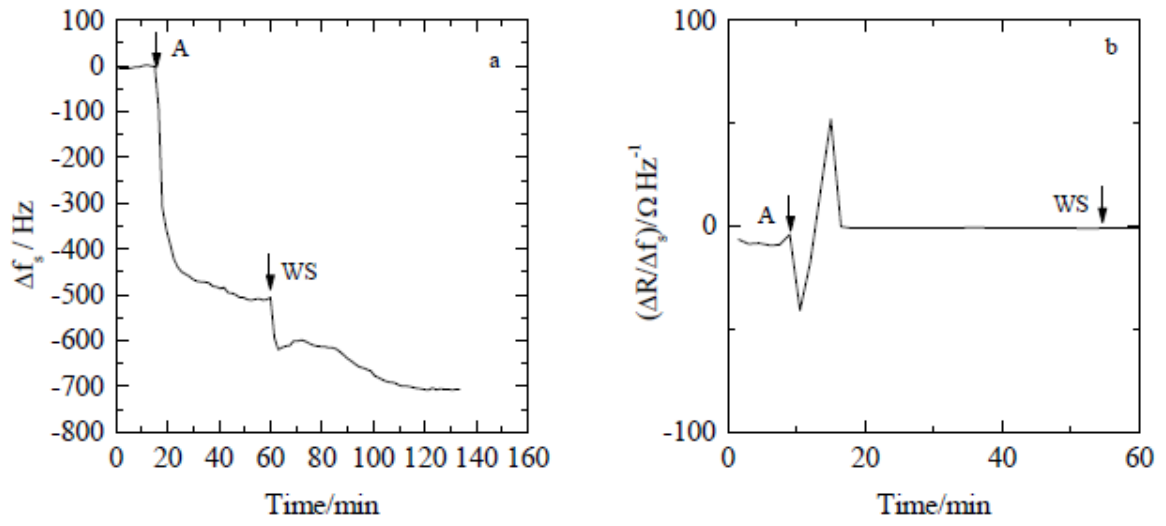
Figure5

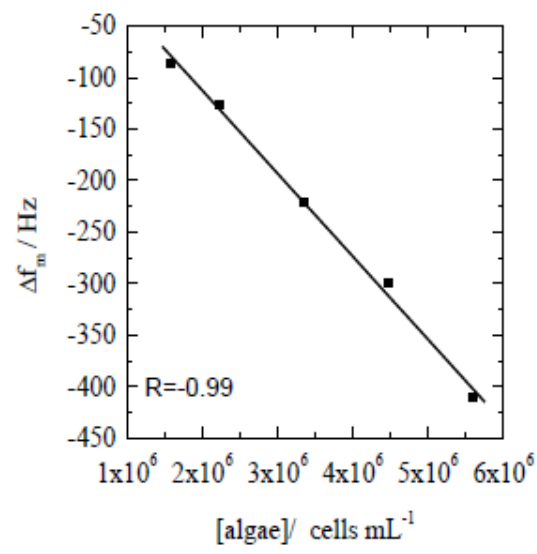


Figure6
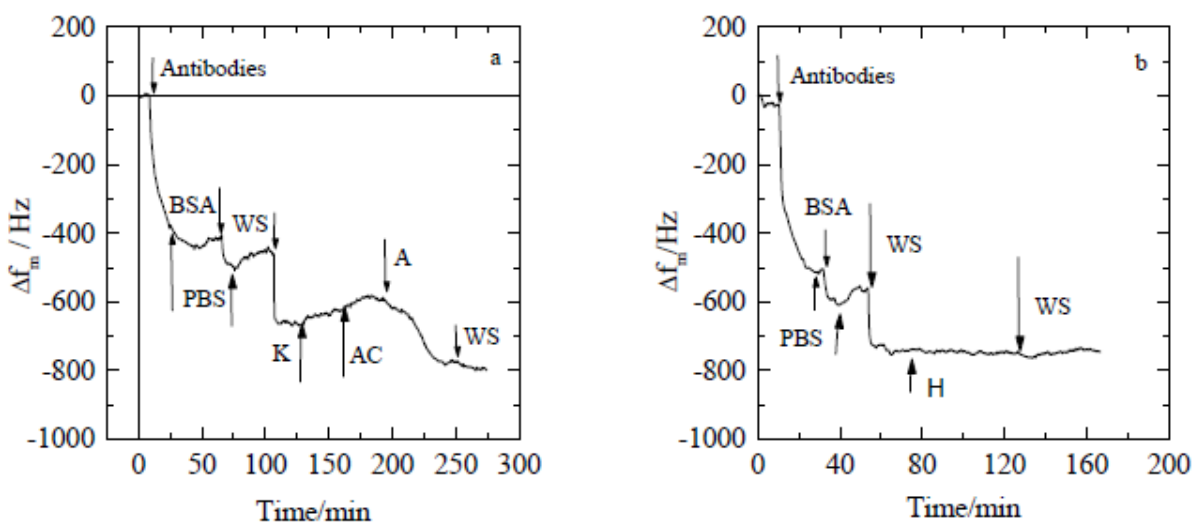